\title{
RESPON ESTRUS KUDA LOKAL DENGAN INDUKSI HORMON PGF2a DI KOTA PAYAKUMBUH
}

\author{
HARISATRIA ${ }^{1}$, D. SURTINA ${ }^{1}$, J. HENDRI ${ }^{1}$ DAN JASWANDI ${ }^{2}$ \\ Universitas Mahaputra Muhammad Yamin'1, Universitas Andalas ${ }^{2}$ \\ Email: haris_satrai85@yahoo.com
}

\begin{abstract}
This study aims to determine the response of local female horse horns employed using the technique of intramuscularly induced hormone prostaglandin F2 alpha (PGF2a). The sample used in this study was 20 female horses with ages 5-10 years who are not in a state of pregnancy or at the time of the luteal phase. The estrus synchronization method was performed by inducing PGF2a (Prostaglandin) at a dose of $10 \mathrm{mg}$ i.m at 08.00 am before horse livestock was employed. Observations of estrous behavior were performed from one day after induction of PGF2a to the appearance of estrus signals. Observation of estrus behavior was done by scoring system according to Colemandan Powell. The data of the research are analyzed descriptively and presented in the mean and standard deviation. The horse estrus response induced by $10 \mathrm{mg}$ i.m PGF2a exhibited numerous estrus symptoms at scoring 3 of 8 with a percentage of $40 \%$ and with an average of $3.05 \pm 0.88$. When seen from the day began to respond to horse cattle after induced PGF2a hormone is relatively fast at $4.25 \pm 1.01$ days.
\end{abstract}

Keywords: estrus, horse, $P G F 2 \alpha$

\section{PENDAHULUAN}

Kegunaan kuda lokal Indonesia sebagian besar adalah sebagai sarana transportasi dan pengangkut barang, sarana hiburan, dan juga sebagai bahan pangan masyarakat lokal. McGregor dan Morris (1980), menyatakan kuda poni di Indonesia merupakan salah satu sarana yang dapat digunakan untuk transportasi dan pengembangan peternakan. Dengan mempekerjakan kuda betina terlalu lama, tingkat efisiensi reproduksi sangat menurun seperti tidak teraturnya siklus estrus, lama estrus dan semakin sulitnya medeteksi estrus pada ternak kuda yang akan mengakibatkan rendahnya tingkat konsepsi/kebuntingan serta rendahnya tingkat kelahiran (Blakely dan Bade, 1995).

Lama estrus pada ternak kuda bervariasi dan terkait dengan waktu berlangsungnya ovulasi. Kisaran terjadi ovulasi pada kuda adalah 4-6 hari setelah mulainya estrus atau 1-2 hari sebelum akhir estrus. Panjang siklus estrus dan waktu ovulasi bervariasi dalam hubungannya dengan faktor-faktor eksternal maupun internal. Pada tingkat ovarium, periode estrus ditandai dengan sekresi estrogen yang tinggi dari folikel preovulatorik. Estrogen merangsang pertumbuhan uterus melalui mekanisme yang meyebabkan interaksi antara hormon dengan reseptornya dan meningkatnya berbagai proses sintesis yang terjadi di dalam sel. Estrogen juga merangsang produksi prostaglandin oleh uterus. Pada akhir estrus, terjadi ovulasi yang diikuti dengan pembentukan korpus luteum (CL) yang akan menghasilkan hormone progesteron (Hafez dan Hafez, 2000).

Selanjutnya untuk mempercepat terjadinya estrus atau penyerentakkan estrus pada ternak kuda bisa dilakukan dengan pemberian hormon. Penyerentakan birahi bertujuan untuk mengendalikan siklus birahi sehingga birahi pada ternak betina terjadi secara serentak pada hari yang sama (Toelihere, 1981; Partodihardjo, 1995). Penyerentakan birahi akan memudahkan pelaksanaan inseminasi buatan karena dapat dikerjakan dalam waktu yang bersamaan dan waktu tunggu untuk terjadinya birahi dapat dipersingkat.

Prostaglandin F2a (PGF2a) merupakan salah satu preparat yang sering digunakan untuk program penyerentakan birahi pada ternak melalui pengaruhnya dalam meregresi korpus luteum (Milvae et al., 
1996). Penyuntikan PGF2a pada program penyerentakan birahi dilakukan dua kali dengan jarak 11-12 hari dan akan menimbulkan birahi pada ternak antara hari ke 2-7 dan puncaknya terjadi pada hari ke 3 setelah penyuntikan kedua (Mac Millan, 1983). Maka dari itu dilakukan penelitian dengan tujuan untuk mengetahui respon penyuntikan hormone PGF2 $\alpha$ terhadap munculnya estrus pada kuda lokal di Kota Payakumbuh.

\section{MATERI DAN METODE}

Materi yang digunakan dalam penelitian ini adalah kuda lokal betina yang dipekerjakan dengan umur 5-10 tahun sebanyak 20 ekor yang tidak dalam keadaan bunting yang ditandai dengan hasil palpasi rectal. Metode singkronisasi estrus dilakukan dengan penyuntikan PGF2a (prostaglandin) dengan merek dangang Capriglandin secara intra muscular menggunakan spuit $5 \mathrm{ml}$ dengan dosis $10 \mathrm{mg}$ i.m pada jam 08.00 pagi atau sebelum ternak kuda dipekerjakan. Pengamatan tingkah laku estrus dilakukan mulai dari satu hari pemberian PGF2a sampai munculnya tanda-tanda estrus. Pengamatan tingkah laku estrus ini dilakukan dengan sistem scoring menurut Coleman dan powell (2004) dan dianalisis skor berahi dianalisis secara deskriptif untuk mencari rataan dan standar deviasi menurut Steel dan Torrie (1999).

Tabel 1 Skor tanda berahi

\begin{tabular}{cl}
\hline Skor & \multicolumn{1}{c}{ Tanda tanda estrus pada kuda betina } \\
\hline 0 & Tidak menunjukkan tanda estrus, tidak keluar lendir, bahkan agresif menyerang, \\
1 & menendang dan meringkik \\
2 & Tenang didekati pejantan \\
3 & $\begin{array}{l}\text { Mendekati pejantan, menunjukkan winked vulva dan mengangkat ekor } \\
4\end{array}$ \\
Mengangkat ekor, squatting, urinisasi \\
berkelanjutan
\end{tabular}

\section{HASIL DAN PEMBAHASAN}

\section{Respon Berahi Ternak Kuda}

Seluruh ternak kuda yang diinduksi dengan 10 mg i.m PGF2a memperlihatkan gejala estrus. Hal tersebut menunjukkan saat perlakuan, siklus estrus kuda sedang berada pada fase luteal yang ditandai oleh responya hormon PGF2a yang di suntikkan. Walaupun semua kuda yang disuntikkan hormon PGF2a memperlihat kan gejala estrus, namun jika diamati dari hasil scoring menurut Coleman dan Powell (2004), tanda-tanda estrus pada kuda tersebut sangat bervariasi yaitu scoring 1 sebanyak 1 ekor, scoring 2 sebanyak 3 ekor, scoring 3 sebanyak 8 ekor dan scoring 4 sebanyak 7 ekor dengan rata-rata 3,05 $\pm 0,88$ scoring, namun persentase tertinggi pada scoring
3 yaitu 40\% dengan tanda-tanda kuda mengangkat ekor, squatting, urinisasi. Sedangkan pada skor 4 hanya 35\% dengan tanda-tanda mengangkat ekor, squatting, urinisasi, winked vulva, berlendir dan urinisasi berkelanjutan.

Tingkah laku selama estrus bervariasi di antara individu kuda, tetapi cenderung tetap pada individu yang sama. Tandatanda estrus yang dapat diamati diantaranya penerimaan terhadap pejantan, ekor terangkat, sering urinasi, vulva mengalami kontraksi ritmik (winking) dan cara berdiri semi jongkok (squatting) (Coleman \& Powell 2004). Menurut Waring (2003) pada saat estrus, kuda akan menjadi relatif lebih jinak dengan kehadiran pejantan dan akan membiarkan pejantan untuk mengendus, menyundul dan menggigit, serta kadang- 
kadang meringkik. Hafez dan Hafez (2000) menambahkan selama periode estrus, vulva akan sedikit membengkak, bagian bibirnya akan mengendur dan akan mudah dibuka ketika diperiksa. Vulva berwarna kemerah-merahan, basah, mengkilap dan kadang-kadang diselapisi lendir yang bening.

Tingkah laku kuda betina pada kondisi diestrus dicirikan dengan penolakan terhadap pejantan. Ketika pejantan mendekat, telinga akan diarahkan ke belakang sebagai tanda marah, menunjukkan sikap gelisah. Kuda betina kadang-kadang menunjukkan respons dengan mengibaskan ekor. Kuda betina akan menghindari pejantan dengan bergerak menjauh, meringkik, menggigit, bahkan menendang pejantan (Waring 2003).

Hal ini sesuai dengan pendapat Prihatno (2003), Listiani (2005), dan Ahola et al. (2009), bahwa efektivitas sinkronisasi berahi menggunakan hormon PGF2a sangat tinggi yakni mencapai persentase berahi $100 \%$ masing-masing pada sapi potong, $\mathrm{PO}$, dan sapi perah yang diinduksi secara intramuskuler. Hyland et al. (2009) dan Skarzynski et al. (2009) melaporkan hal yang sama masingmasing pada sapi Holstein dan sapi potong. Bervariasinya tanda-tanda estrus pada kuda lokal yang di beri hormon PGF2a, hal ini diduga karena tingkat kesuburan ternak yang berbeda dan faktor dari diperlakukannya ternak kuda sebagai alat transportasi.

\section{Kecepatan Munculnya Estrus Kuda}

Apabila dilihat dari hari mulai meresponnya ternak kuda setelah diberikan hormon PGF2a tergolong cepat yaitu pada 4,25 $\pm 1,01$ hari. Hal ini tergolong normal dan sesuai dengan pendapat Estrada et al. (2003) yang menyatakan bahwa dengan penggunaan 7,5 mg PGF2a yang dilakukan akan menyebabkan onset estrus dalam jangka waktu3-4 hari dan ovulasi dalam jangka waktu 8-10 hari. Menurut Samper (2008) kisaran antara pemberian PGF2a sampai dengan onset estrus dan tercapainya ovulasi dapat berkisar berturut-turut pada 48 jam dan 12 hari, tergantung dari diameter folikel yang akan mengalami ovulasi.

Jika pada ovarium terdapat folikel besar pada saat penyuntikan, ovulasi akan terjadi dalam kurun waktu 72 jam tanpa menunjukkan gejala estrus yang jelas. Namun demikian menurut Samper et al. (1993) jika folikel telah mencapai diameter maksimal selama fase luteal yang didominasi oleh progesteron, maka folikel ini akan mengalami regresi, dan akan terjadi perekrutan folikel-folikel baru, sehingga estrus dan ovulasi akan mengalami penundaan.

Selanjutnya siklus reproduksi kuda sangat terkait erat dengan berbagai fenomena, meliputi pubertas dan kematangan seksual, musim kawin, siklus estrus, aktivitas seksual setelah beranak, dan penuaan atau umur. Faktor yang mengatur hal tersebut di atas adalah lingkungan, genetik, fisiologi, hormonal, tingkah laku dan faktor-faktor psikososial. Ketika tercapai pubertas, sekresi gonadotropin juga akan mengalami peningkatan (Hafez dan Hafez, 2000). Sementara itu, Johnson dan Everitt (1995) menyatakan lamanya siklus ovarium yang di dalamnya terdapat fase folikuler dan luteal akan berbeda pada masingmasing spesies. Berdasarkan pengamatan tingkah laku estrus, panjang siklus estrus pada kuda betina adalah 20-24 hari (Hafez dan Hafez, 2000).

Timbulnya berahi akibat pemberian PGF2a disebabkan karena lisisnya CL oleh mekanisme kerja PGF2a melalui mekanisme apoptosis dan mekanisme aktivasi protein kinase (PKC) yang menghambat konversi kolesterol menjadi progesteron (Maidaswar, 2007). Akibatnya kadar progesteron yang dihasilkan oleh CL menurun dalam darah. Penurunan kadar progesteron ini merangsang 
hipofisa anterior menghasilkan dan melepaskan follicle stimultaing hormone (FSH) dan luteinizing hormone (LH). Kedua hormon ini bertanggung jawab dalam proses folikulogenesis dan ovulasi, sehingga terjadi pertumbuhan dan pematangan folikel. Folikel-folikel tersebut akhirnya menghasilkan hormon estrogen yang mampu memanifestasikan gejala berahi (Jainudeen dan Hafez, 2000). Kerja hormon estrogen adalah untuk meningkatkan sensitivitas organ kelamin betina yang ditandai perubahan pada vulva dan keluarnya lendir (Lammoglia et al., 1998).

\section{KESIMPULAN}

Respon estrus kuda yang diinduksi dengan 10 mg i.m PGF2a memperlihatkan gejala estrus yang banyak pada scoring 3 sebanyak 8 ekor dengan persentase $40 \%$ dan dengan rata-rata 3,05 $\pm 0,88$. Apabila dilihat dari hari mulai meresponya ternak kuda setelah diinduksi hormon PGF2a tergolong cepat yaitu pada 4,25 $\pm 1,01$ hari.

\section{DAFTAR PUSTAKA}

Ahola, J.K., G.E. Seidel Jr., and J.C. Whittier. 2009. Use gonadotropin releasing hormone at fixed time artificial insemination at eighty or ninety seven hours post prostaglandin F2a in beef cows administered the long term melengestrol acetate select synch. The Professional Animal Scientist (25):256-261.

Blakely, J. dan Bade, D.H. 1995. Ilmu Peternakan, 4th Alih Bahasa : Srigandono, B. dan Soedarsono (Judul Asli The Science Of Animal Hubandry, 4 th ed.). Gadjah Mada University Press. Yogyakarta. hal 668-689.

Coleman RJ, Powell D. 2004. Teasing Mares. Cooperative Extention Service. University of Kentucky-College of Agriculture. www.ca.uky.edu. 25 Mei 2011.

Hafez, E.S.E and B Hafez. 2000a. Anatomy of Female Reproduction. In: Hafez E. S. E and B Hafez (Eds). Reproduction in Farm
Animals. $7^{\text {th }}$ ed. Lippincot Willkins \& Wilkins, Philadephia.

Hyland, J.H. dan F. Bristol. 1979. Synchronization of oestrus and timed insemination of mares. J Reprod. Fertil. Suppl.(27):251-255.

Jainudeen, M.R. and E.S.E. Hafez. 2000. Cattle and Buffalo. In Reproduction in Farm Animals. Hafez, B. and E.S.E. Hafez (Ed.). $7^{\text {th }}$ Lippincott Williams \& Wilkins, Philadelphia.

Johnson MH, Everitt BJ. 1995. Essential Reproduction. Ed ke-4. USA: Blackwell Science.

Lammoglia, M.A., R.E. Short, S.E. Bellows, M.D. Macneil, and H.D. Hafs. 1998. Induced and synchronized estrus in cattle. J. Anim. Sci. 76:1662-1670.

Listiani, D. 2005. Pemberian PGF2a pada Sapi Peranakan Ongole yang Mengalami Gangguan Korpus Luteum. Tesis. Program Pascasarjana Universitas Diponegoro. Semarang.

Macmillan, K.L. 1983. Prostaglandin Response in Dairy Herd Breeding Programs. Journal Veterinary. 31: 110-113.

McGregor, P. Dan Morris. 1980. The Complete Book of Horse. QED Publishing Ltd, Feltham.

Maidaswar. 2007. Efisiensi Superovulasi pada Sapi Melalui Sinkronisasi Gelombang Folikel dan Ovulasi. Tesis. Program Pascasarjana Institut Pertanian Bogor. Bogor.

Milvae, R.A., Hinckly, S.T., and Carlson, J.C. 1996. Luteotropic and Luteolytic Mechanism in the Bovine Corpus Luteum. J. Theriog. 45 : 1327-1349.

Partodihardjo, S. 1995. Ilmu Reproduksi Hewan. Fakultas Veterinary Institut Pertanian Bogor. Bogor.

Prihatno, S.A. 2003. Pengaruh pemberian prostaglandin $\mathrm{F}-2 \mathrm{a}$ dan methilergometrin 
terhadap timbulnya estrus setelah beranak pada sapi perah. J. Sain Vet. 21(1):55-59.

Steel, R. G. D. dan J. H. Torrie 1999. Prinsip dan Prosedur statistika. Edisi ke-2. Gramedia Pustaka Utama, Jakarta.

Samper, J. C. 2008. Induction of estrus and ovulation: Why some mares respond and others do not. Theriogenology 70: 445-447.

Samper, J. C., H. Geertsema and P. Hearn. 1993. Rate of luteolysis, folliculogenesis and interval to ovulation of mares treated with a prostaglandin analogue on $\mathrm{d} 6$ or 10 of the estrous cycle. Proc. Am. Assoc. Equine Pract: 169-71.
J.J. Jaroszewski. 2009. In vitro assessment of progesterone and prostaglandin E2 production by the corpus luteum in cattle following pharmacological synchronization of estrus. J. Reproduct. Developm. 55(2):170-176.

Toelihere, M. 1981. Fisiologi Reproduksi padaTernak. Angkasa. Bandung.

Waring, G. H. 2003. Horse Behavior. 2nd edn. Noyes Publication William Andrew Publishing, New York. 